\title{
ESTIMATION OF RESILIENCE OF UKRAINIAN INDUSTRY TO SHOCK INFLUENCES: COMPARATIVE ANALYSIS
}

\author{
Larysa Lebedeva \\ Department of Economics and Competition Policy \\ Kyiv National University of Trade and Economics \\ 19 Kyoto str., Kyiv, Ukraine, 02156 \\ Irina Shtunder \\ Department of Economics and Competition Policy \\ Kyiv National University of Trade and Economics \\ 19 Kyoto str., Kyiv, Ukraine, 02156 \\ Tamila Scherbakova \\ Department of Economics and Competition Policy \\ Kyiv National University of Trade and Economics \\ 19 Kyoto str., Kyiv, Ukraine, 02156 \\ Viktoriya Khrustalova \\ Department of Economics and Competition Policy \\ Kyiv National University of Trade and Economics \\ 19 Kyoto str., Kyiv, Ukraine, 02156
}

\begin{abstract}
The study of resilience of the industrial sector to shock influences is especially urgent taking into account the constant instability of the economic and political environment in Ukraine and in the world. The aim of the paper is to determine the resilience level of Ukrainian industry to shock influences for improving state support programs for industrial production and decreasing negative results of shock influences on economy of the country. Thus, the object of the study is Ukrainian industry. Methods of comparative analysis have been used in the paper. Based on parameters of economic safety, there have been determined main indicators that allow to estimate the resilience level of industry to external and internal shocks. These indicators include estimation of the condition of industry of the country, namely: its ability to keep balance and to renew itself after shocks, general parameters of economic effectiveness such as labor productivity, labor intensity, profitability of operational activity, indices of the level of technological support of industry. Resilience to shocks of the external sector is presented by the analysis of indicators of export-import operations. For objectivity of the conducted analysis, indicators of Ukrainian industry have been compared with European countries. According to the results of the conducted analysis, the conclusion has been made about the unstable condition of Ukrainian industry, because eleven of thirteen analyzed indicators are beyond threshold values, and only two ones: labor intensity of industrial production and a share of manufacturing industry in GDP are lower or within a threshold value. For providing the growth of industrial production in separate regions of Ukraine, there it has been offered to create a base productions in industry. The following base productions have been determined in Ukrainian industry: production of engines of different types, semiconductors and microelectronics, constructor materials, diverse products of inter-branch destination.
\end{abstract}

Keywords: resilience, industry, shock influences, profitability, innovations, employment, Ukraine.

\section{Introduction}

The direction of this study is especially urgent after the second economic crisis of 2008 2009 years, when added value in industry, including building sector reduced by $4.62 \%$ in the world and by $19.47 \%$ in Ukraine. Socio-economic results of this crisis that coincided with socio-political processes in Ukraine in 2013-2014 years threaten the competitiveness of national economy and its long-term growth. Especially, Ukraine lowered by 11 positions to 84 place in the rating of the World economic forum about competitiveness of world economies in 2013-2014. The reduction on Ukrainian GDP by $6.55 \%$ took place in the same period. 
We think that the scientifically grounded determination of the resilience degree of Ukrainian industry to negative external influences will favor the improvement of state support programs for industrial production and decrease of negative results of shock influences on economy of the country, and also will help to understand, which shocks need a correspondent reaction of the state and will have more influence of introducing regulating arrangements of the state for renewal and increase of the resilience level of economy in whole.

Let's consider three widespread scientific approaches to studying the resilience of national economy. The first one is through the standard analysis of business cycles, dividing economic data in general-trend and cyclic components, and associating cyclic components with temporary deviations from a trend because of macroeconomic shocks. The second one - the adjustment of economy to shocks is studied through the variation methodology, analyzing the reaction of macroeconomic variables to unpredictable shock influences. And the last, the dynamic stochastic general modeling of balance, where the structural economic model, which parameters are verified or calculated, is used for determining the influence of shocks on economy $[1,2]$.

According to the first method, fluctuations of a business cycle are divided in general components (that fix the synchronized part of a reaction to shocks by countries) and idiosyncratic components (that fix the non-synchronized part of a reaction). Idiosyncratic reactions may exist by two causes: because of shocks, typical for a country or market, or because different countries or markets have different resilience to general disturbances. In whole, observations of idiosyncratic fluctuations of business-cycle motivated scientists to try to estimate a reaction of macroeconomic parameters as a response to economic shocks in the aspect of resilience that economy "opposes" to the influence of general disturbances with. But for estimating economic parameters in such a way, a distinct definition of "resilience" and shocks that must be studied, is necessary.

Foreign scientists $[3,4]$ define resilience as an ability of countries to support an output, close to the potential, after shocks. It is measured by two ways: by analyzing, how strong the influence of global shocks on the decline of national production is (amplification effect) and how fast it is eliminated after shocks (persistence effect). Changes of parameters, connected with the production decrease, measure the persistence effect, and ones, connected with shocks, - amplification effect.

A difference between the amplification effect and resilience to negative external effects is essential, because institutes that help to weaken the shock influence can do them more resilient. For example, the strict regulation of employment can prevent firms from dismissing workers, favoring stabilization and consumption level in the shot-term prospect. But the same state intervention can result in increasing costs of enterprises and longer renewal in final, delaying its production renewal in a potential value.

Then scientists [5] have analyzed how institutes influence an amplification effect and persistence effect of shock results, measuring these parameters through institutional changes of the commodity market and labor one. The set of institutional variables included: (I) change of redundancy award; (II) rigid legislation about employment protection; (III) rigid regulation of the commodity market in seven non-production branches; (IV) payments at dismissal; and (V) degree of centralization of fixing a salary. Variables (II), (III) and (V) turned to be the most important in explaining differences in amplification and persistence effects of shocks. For having a possibility to take into account other factors that can influence resilience, a share of mortgage debt of households to GDP, share of bank credits to the market value of safety stocks (differences in monetary and credit policy) and share of the total volume of tax incomes to GDP (differences in the volume of automatic stabilizers) have been included as regressors. In whole the research results indicate that rigid rules of state regulation of the labor market soften a short-term shock effect, but make shock results stronger.

Native scientists [6] note that industry and agriculture in Ukraine are determining sources of the economic development that directly influence its resilience. Resilience of the bank economic sector is rather important and studied in literature; scientists [7] note that it directly influences the general resilience of economy to shock influences. Other scientists [8] define enterprising sector resilience to shock influences as a possibility of renewal after a crime, unwell competition or xenophobia. Scientific literature also underlines the importance of formation and development of infor- 
mational economy, modern high-technological economic branches for accelerating the economic development of the country and its resilience support [9].

Reforms that liberalize commodity markets, raise resilience of economy at least by two ways $[10,11]$ : by the effective distribution and by the effective production. Liberalization of commodity markets may increase the effectiveness of resource distribution, simplifying entering at the market, and also at the expanse of increasing its competitiveness that provides the faster redistribution of resources both within a branch and between them.

Microeconomic theory connects changes in demand with changes of incomes through elasticity of demand (costs) for different goods. At economic declines, when people see that their personal incomes fall, the relative demand for goods and services changes according to elasticity of demand for products. The research results testify that the sector of consumption goods is more resilient than one of investments or intermediate goods [12].

So, a lot of works in economic literature are devoted to the problem of resilience of economy and its sectors, but not enough attention is paid to the analysis of its separate branches, especially industry. From our point of view, industry plays a central role in the development of Ukrainian economy that is why it is urgent today under conditions of essential economic instability to study the support of its ability to resist shocks.

\section{Aim of research}

The main aim of the study is to determine the level of resilience of Ukrainian industry to shock influences and to compare resilience indicators with European countries.

\section{Materials and Methods}

Based on economic safety parameters, let's determine main indicators that allow to estimate the resilience level of industry to external and internal shocks qualitatively [made by the author by 13] (Table 1).

Table 1

Indicators for estimating the resilience level of industry to external negative influences

\begin{tabular}{|c|c|c|}
\hline Name of indicator measurement units & $\begin{array}{l}\text { Thresh- } \\
\text { old values }\end{array}$ & Calculation order of indicator \\
\hline 1 & 2 & 3 \\
\hline 1. Share of manufacturing industry in GDP, percent & $20-30 \%$ & $\begin{array}{l}\text { Volume of realized products of manufacturing industry / } \\
\text { GDP of Ukraine (in real prices) }\end{array}$ \\
\hline 2. Population employment level in industry, percent & $20-30 \%$ & $\begin{array}{c}\text { Number of population, employed in industry / } \\
\text { employed population }\end{array}$ \\
\hline $\begin{array}{l}\text { 3. Wear and tear degree of main industrial means, } \\
\text { percent }\end{array}$ & $30-60 \%$ & - \\
\hline $\begin{array}{l}\text { 4. Share of high-technological products in the total } \\
\text { volume of realized industrial products, percent }\end{array}$ & $3-5 \%$ & $\begin{array}{l}\text { Production of computers, electric and optic products / } \\
\text { volume of realized industrial products, work, services in out- } \\
\text { put prices of an enterprise (without VAT and excise) }\end{array}$ \\
\hline 5. Labor intensity of industrial production, percent & $10-15 \%$ & $\begin{array}{l}\text { Expenditures for staff at industrial enterprises, mln hrn / } \\
\text { volume of realized industrial products, work, services in out- } \\
\text { put prices of an enterprise (without VAT and excise), } \\
\text { mln hrn } \times 100\end{array}$ \\
\hline $\begin{array}{l}\text { 6. Profitability of operational activity of industrial } \\
\text { enterprises, percent }\end{array}$ & $5-10 \%$ & - \\
\hline $\begin{array}{l}\text { 7. Volume of products of high manufacturing } \\
\text { degree, realized abroad, percent }\end{array}$ & $10-15 \%$ & $\begin{array}{c}\text { Capital equipment (except transport), components, parts and } \\
\text { devices for it, transport equipment, components, parts and } \\
\text { devices for it, to total export, } \%\end{array}$ \\
\hline & & 22 \\
\hline
\end{tabular}




\section{Continuation of Table 1}

\begin{tabular}{lcc}
\hline \multicolumn{1}{c}{ Continuation of Table 1 } & $\mathbf{2}$ & $\mathbf{3}$ \\
\hline $\begin{array}{l}\text { 8. Share of industrial goods in export to GDP, percent } \\
\text { 9. Share of industrial goods in import to GDP, percent }\end{array}$ & $\begin{array}{l}15-20 \% \\
\text { No more }\end{array}$ & $\begin{array}{c}\text { Industrial goods in export, mln USD/GDP } \\
\text { Industrial goods in import, mln USD/GDP } \\
\text { services, mln hrn + export goods and services, } \\
\text { mln hrn + import of goods and services, mln hrn) }\end{array}$ \\
$\begin{array}{l}\text { 10. Share of import in internal consumption, percent } \\
30 \%\end{array}$ & $70-80 \%$ & - \\
$\begin{array}{l}\text { 11. Share of products, realized at competitive } \\
\text { markets, percent of the total volume of products }\end{array}$ & & \\
$\begin{array}{l}\text { 12. Specific weight of enterprises that introduced } \\
\text { innovations in the total number of industrial } \\
\text { enterprises, percent }\end{array}$ & $30 \%$ & - \\
$\begin{array}{l}\text { 13. Specific weight of realized innovative products, } \\
\text { percent }\end{array}$ & $10-15 \%$
\end{tabular}

Using this system of indicators, it is possible to estimate how resilient industry of a country is to both internal and external shocks. Indicators include the estimation of the condition of industry of a country, namely: its ability to keep balance and to renew itself after shocks, general parameters of economic effectiveness such as labor productivity, labor intensity, profitability of operational activity. There included also the level of technical support of industry that is important for resilience of economy in whole. Resilience of industry to shocks of the external sector is presented by indices of export-import operations.

\section{Results}

Let's use parameters, presented in Table 1.

The share of manufacturing industry in GDP, percent. Manufacturing industry supports resilience of economy by providing own production with products with a high added value. Due to the essential share of manufacturing industry in GDP, economy of a country is able to form the stable potential for the economic growth.

The share of manufacturing industry in Ukrainian GDP decreases in advanced rates comparing with extracting industry (Table 2).

\section{Table 2}

Share of extracting and manufacturing industry in production and distribution of gross domestic product of Ukraine, percent [14, p. 204]

\begin{tabular}{ccccc}
\hline Type of economic activity & Year & Output & Intermediate consumption & Gross added value \\
\hline Extracting industry & 2001 & 4.8 & 5.3 & 4.2 \\
& 2005 & 3.9 & 3.8 & 4.1 \\
& 2010 & 4.8 & 3.9 & 5.8 \\
& 2013 & 4.6 & 3.9 & 5.4 \\
Manufacturing industry & 2014 & 4.4 & 3.9 & 5.0 \\
& 2015 & 4.4 & 3.6 & 5.6 \\
& 2001 & 35.7 & 49.0 & 17.4 \\
& 2005 & 38.1 & 51.4 & 19.7 \\
& 2010 & 32.2 & 45.9 & 3.9 \\
& 2013 & 26.8 & 39.6 & 11.1 \\
\end{tabular}


If in 2001 the ratio between manufacturing and extracting industry by the products output was 7.4; by intermediate consumption 9.2, by gross added value 4.2, in 2015 these indices were 6.5; $10.7 ; 2.5$ respectively. The share of manufacturing industry decreased most essentially from 17.4 to $14.0 \%$. The analogous index in extracting industry on the contrary increased from 4.2 to $5.6 \%$. So, the share of manufacturing industry in GDP of Ukraine in 2001-2015 had a tendency to decrease and was $28.7 \%$, but within threshold values $20-30 \%$ of GDP.

The shares of extracting and manufacturing industry in GDP of EU-28 have also a tendency to decrease (Table 3). In Germany - leading EU country by the economic development - the share of extracting industry is less $-0.42 \%$, but the one of manufacturing industry is higher than the average index $-67.47 \%$, that proves the industrial development of this country.

In Poland that is closer to Ukraine by the economic development, the share of extracting industry in GDP is $2.79 \%$, manufacturing - $67.20 \%$. In Ukraine these indices were $4.4 \%$, and $28.7 \%$ respectively in 2015 (Table 2). From this comparison we can see the lag of the Ukrainian industrial development, namely manufacturing industry from the developed world countries in the share of producing and maintaining the national economy growth, namely at the expanse of products with a high added value.

Table 3

Extracting and manufacturing industry in EU-28, Germany and Poland [15]

\begin{tabular}{|c|c|c|c|c|c|c|c|}
\hline No. & Years & 2010 & 2011 & 2012 & 2013 & 2014 & 2015 \\
\hline \multicolumn{8}{|c|}{ European Union-28 } \\
\hline 1 & GDP, bil euro & 12814.2 & 13189.2 & 13449.0 & 13560. & 13987.3 & 14797.4 \\
\hline 2 & Extracting industry, bil euro & - & 252.0 & 260.2 & 250.5 & 228.0 & 197.2 \\
\hline 3 & Manufacturing industry, bil euro & - & 7000.0 & 7080.0 & 6980.0 & 6984.5 & 7320.0 \\
\hline 4 & $\begin{array}{l}\text { Share of extracting industry in } \\
\text { GDP, percent }\end{array}$ & - & 1.91 & 1.93 & 1.85 & 1.63 & 1.33 \\
\hline 5 & $\begin{array}{l}\text { Share of manufacturing industry in } \\
\text { GDP, percent }\end{array}$ & - & 53.07 & 52.64 & 51.47 & 49.93 & 49.46 \\
\hline \multicolumn{8}{|c|}{ Germany } \\
\hline 6 & GDP, bil euro & 2580.1 & 2703.1 & 2758.3 & 2826.2 & 2923.9 & 3041. 0 \\
\hline 7 & Extracting industry, bil euro & 13.3 & 13.7 & 13.2 & 12.7 & 13.0 & 12.9 \\
\hline 8 & Manufacturing industry, bil euro & 1750.1 & 1956.1 & 1967.7 & 1975.8 & 2021.6 & 2051.9 \\
\hline 9 & $\begin{array}{l}\text { Share of extracting industry in } \\
\text { GDP, percent }\end{array}$ & 0.51 & 0.51 & 0.48 & 0.45 & 0.44 & 0.42 \\
\hline 10 & $\begin{array}{c}\text { Share of manufacturing industry in } \\
\text { GDP, percent }\end{array}$ & 67.83 & 72.36 & 71.34 & 69.91 & 69.14 & 67.47 \\
\hline \multicolumn{8}{|c|}{ Poland } \\
\hline 11 & GDP, bil euro & 361.7 & 380.2 & 389.3 & 394.6 & 410.9 & 430.0 \\
\hline 12 & Extracting industry, bil euro & 12.5 & 14.7 & 14.5 & 13.8 & 12.5 & 12.0 \\
\hline 13 & Manufacturing industry, bil euro & 235.7 & 265.1 & 271.4 & 270.7 & 281.2 & 289.9 \\
\hline 14 & $\begin{array}{l}\text { Share of extracting industry in } \\
\text { GDP, percent }\end{array}$ & 3.45 & 3.87 & 3.72 & 3.49 & 3.03 & 2.79 \\
\hline 15 & $\begin{array}{l}\text { Share of manufacturing industry in } \\
\text { GDP, percent }\end{array}$ & 65.16 & 69.73 & 69.73 & 68.61 & 68.46 & 67.20 \\
\hline
\end{tabular}


The population employment level in industry, percent. The employment of population supports resilience of the economic industrial sector at the expanse of the rational use of existent production resources. The number of employed in industry has a stable tendency to decrease, which rates are higher than the average ones in economy of Ukraine (Fig. 1).

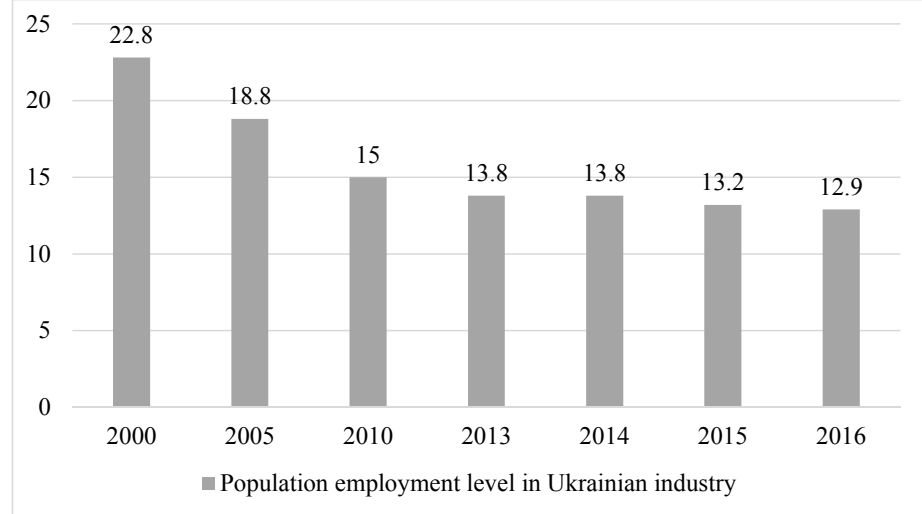

Fig. 1. Population employment level in Ukrainian industry, percent of whole employed population $[14$, p. 51]

If in 2000 it reached $22.8 \%$ of whole employed population, in $2016-12.9 \%$. By the index of population employment in industry Ukraine is lower than the threshold value $20 \%$ that negatively influences resilience of the economic industrial center. The number of employed in machine engineering decreased by the highest rates. If in whole industry the number of workers decreased from 2000 to 2015 almost twice, in machine engineering - in 3 times.

The analysis of the dynamics of the number of workers by types of industrial activity in EU countries allows to determine the following tendencies. The extracting industry in EU countries occupies almost $1 \%$ of employed, manufacturing one varies from 20 to $25 \%$ of the whole working force, whereas in Ukraine these indices are $12 \%$ and $65.6 \%$ respectively. High-technological sectors of machine engineering became in a difficult situation. Thus, the electric industry in Ukraine is near destruction: the number of employed decreased from 280 thousand persons (in 1990) to 4 thousand persons (in 2015).

In the European Union the percent of employed in industry has a tendency to decrease (Table 4), that completely correlates with processes of decreasing the number of employed in industry in Ukraine. But in industrially developed Germany such tendency is kept as opposite to Poland, where the number of employed in industry remains stable for the last decade.

Table 4

Population employment by types of economic activity (industry) in EU, Germany and Poland, percent [15]

\begin{tabular}{ccccccccc}
\hline Year & $\mathbf{2 0 0 5}$ & $\mathbf{2 0 1 0}$ & $\mathbf{2 0 1 1}$ & $\mathbf{2 0 1 2}$ & $\mathbf{2 0 1 3}$ & $\mathbf{2 0 1 4}$ & $\mathbf{2 0 1 5}$ & $\mathbf{2 0 1 6}$ \\
\hline EU-28 & 24.9 & 22.8 & 22.7 & 22.4 & 22.1 & 21.9 & 15.3 & 15.3 \\
Germany & 25.7 & 24.5 & 24.6 & 24.7 & 24.7 & 24.6 & 18.8 & 18.6 \\
Poland & 29.5 & 30.1 & 30.4 & 30.2 & 30.3 & 30.2 & 23.0 & 23.7
\end{tabular}

In general Poland is closer to Ukraine by the level of economic development. Twice more working population than in Ukraine is engaged in the industrial complex in this country. Such discordance testifies to the insufficiently high level of industrial production in Ukraine. On the contrary in EU there is observed the stable tendency to increasing a share of working population in the service sphere [4]. In EU in whole $73.1 \%$, in Germany and Poland - $73.9 \%$ and $58.3 \%$ respectively. 
The wear and tear degree of main industrial means, percent (Fig. 2). Wear and of main means demonstrate a degree of their correspondence to the modern STP. The high wear and tear degree of main means testifies to the low adjustability of industry to modern challenges, so the low level of its resilience to negative internal and external influences.

The condition of main means in industry decreases the resilience level of the industrial economic sector of Ukraine. The wear and tear degree of main means in economy of the country is $58.1 \%$, and in industry $-69.4 \%$, that indicates the critical wear and tear level of main means in Ukraine, because the threshold value of this index is $35 \%$.

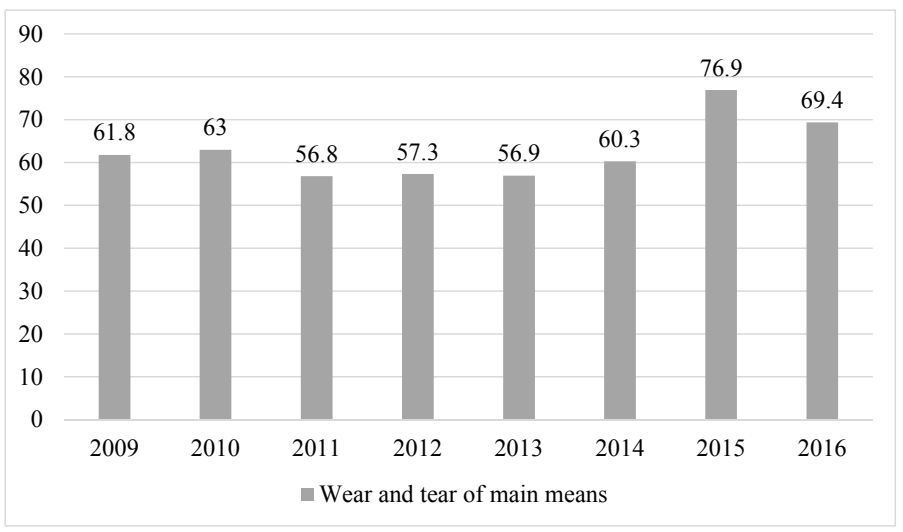

Fig. 2. Wear and tear degree of main means in industry in Ukraine, percent [16]

The share of high-technological products in the total volume of realized industrial products (percent) positively influences resilience formation of the industrial economic sector (Table 5).

Table 5

Share of high-technological products in the total volume of realized industrial products in Ukraine [16]

\begin{tabular}{|c|c|c|c|c|c|c|}
\hline Parameter & 2001 & 2005 & 2010 & 2014 & 2015 & 2016 \\
\hline $\begin{array}{l}\text { Production of computers, electric and optic } \\
\text { products, electric equipment, bil hrn }\end{array}$ & 6.2 & 15.5 & 28.2 & 32.1 & 8.8 & 12.4 \\
\hline $\begin{array}{l}\text { Volume of realized industrial products (goods, } \\
\text { services), bil hrn. }\end{array}$ & 210.8 & 468.6 & 1043.1 & 1428.8 & 1776.6 & 2158.0 \\
\hline $\begin{array}{l}\text { Share of high-technological products in the total } \\
\text { volume of realized industrial products percent }\end{array}$ & 2.94 & 3.31 & 2.71 & 2.24 & 0.49 & 0.57 \\
\hline
\end{tabular}

The more value of this indicator, the more resilient industry to shock influences is. As we can see from Table 5, the indicator of the share of high-technological products in the total volume of realized industrial products in Ukraine for 2016 was $0.57 \%$. This indicator has a stable tendency to decrease since 2001, when it was $2.94 \%$. So, resilience of the industrial sector is threatened, because the threshold index value is 3-5\%.

The labor intensity of industrial production (percent) which content in the context of our study is considered as an indicator, reversed to resilience of the industrial production sector, because the more employed are needed for one unit of a product, the less effective (that is less resilient to shocks) such production is (Table 6).

The labor intensity of industrial production is Ukraine has a tendency to decrease that positively influences the resilience level of the economic industrial sector, reached $8.4 \%$ in 2016 and remained at the level, lower than threshold values (10-15\%).

The profitability of operational activity of industrial enterprises (percent) supports resilience of the industrial sector, because more profit allows enterprises to have more "reserves" for reactions to possible shocks. 
Table 6

Labor intensity of industrial production in Ukraine [16]

\begin{tabular}{lrrrrrrrr}
\hline Parameter & Year & $\mathbf{2 0 1 0}$ & $\mathbf{2 0 1 1}$ & $\mathbf{2 0 1 2}$ & $\mathbf{2 0 1 3}$ & $\mathbf{2 0 1 4}$ & $\mathbf{2 0 1 5}$ & $\mathbf{2 0 1 6}$ \\
\cline { 1 - 6 } Volume of realized industrial products (goods, services), bil hrn & 1043.1 & 1305.3 & 1368.0 & 1322.4 & 1428.8 & 1776.6 & 2158 \\
Expenditures for staff at industrial enterprises, bil hrn & 122.8 & 146.3 & 170.6 & 176.5 & 158.3 & 169.3 & 182.1 \\
Labor intensity of industrial production (percent) & 11.77 & 11.21 & 12.47 & 13.35 & 11.08 & 9.53 & 8.44
\end{tabular}

The profitability of operational activity in industry for the studied period was at level 2-5\% that made impossible full-value crediting, when a price for credit use exceeded 20 percents. At that the profitability level of industrial enterprises remains low and is $4.2 \%$ (Fig. 3), at threshold values $5-10 \%$ that indicates the low resilience level of industrial enterprises, because they are not able to provide a "financial pillow" for themselves in a case of shock fluctuations in economy.

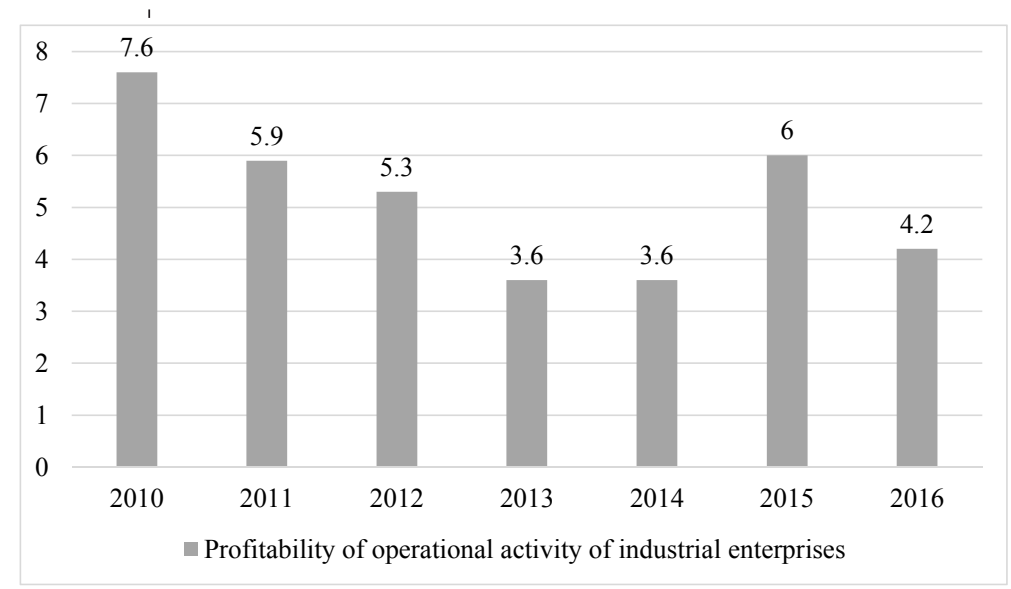

Fig. 3. Profitability of industrial enterprises in Ukraine, percent [16]

The volume of industrial products with the high manufacturing degree, realized abroad (percent) (Table 7), that determines resilience of economy through its competitiveness at the world market. The higher indicator, the more developed the industrial sector of a country is. The parameter is important for providing resilience of the industrial sector, because it shows, what share of products with a high manufacturing degree is supplied abroad by economy of a country. That is what place such economy occupies in the international labor distribution: is it a supplier of raw materials to the world market or one of products with a high added value. The resilience level is directly proportional to the level of "raw material orientation" of economy, because at fluctuations of world prices for raw materials, under conditions of a low share of added value in them, suppliers of raw material products find themselves in a difficult situation for providing their further operational activity.

As it can be seen on Table 7, export of groups of industrial commodities, related to the category of the high manufacturing degree, namely capital equipment (except transport), components, parts and devices for it, transport equipment, components, parts and devices for it in the total export of Ukraine fell from $7.2 \%$ in 2013 to $3.1 \%$ in 2016, at threshold value $10-15 \%$ that indicates that Ukraine belongs to the group of countries that export raw materials and, correspondingly, has the low resilience level to shock influences.

The share of industrial goods in export to GDP, percent. Positively influences resilience of the economic industrial sector, because the more share of export of industrial goods in GDP, the more important place is occupied by economy of a country in the world labor distribution, so, the better it can adjust to shock influences (Table 8). 
Table 7

The distribution of commodity export by wide economic categories, in $\%$ to the total volume of export from Ukraine [17, p. 95]

\begin{tabular}{lcccc}
\hline \multicolumn{1}{c}{ Commodity name } & $\mathbf{2 0 1 3}$ & $\mathbf{2 0 1 4}$ & $\mathbf{2 0 1 5}$ & $\mathbf{2 0 1 6}$ \\
\hline Totally including & 100.0 & 100.0 & 100.0 & 100.0 \\
Food products and drinks & 10.6 & 5.2 & 5.7 & 6.5 \\
Raw materials for industry, not included in other categories & 49.8 & 50.7 & 51.1 & 50.2 \\
Fuel and lubricant materials & 4.1 & 2.6 & 1.0 & 0.9 \\
Capital equipment (except transport), components, parts and & 4.0 & 3.2 & 2.8 & 2.5 \\
devices for it & & 3.2 & 0.6 & 0.6 \\
Transport equipment components, parts and devices for it & 3.2 & 0.0 & 0.0 \\
Passenger cars & 0.1 & 0.0 & 0.6 & 0.6 \\
Other & 3.1 & 1.2 & 3.6 & 3.9
\end{tabular}

Table 8

Share of industrial goods in external trade of Ukraine [17, p. 90]

\begin{tabular}{|c|c|c|c|c|c|c|c|}
\hline Parameter Year & 2010 & 2011 & 2012 & 2013 & 2014 & 2015 & 2016 \\
\hline Industrial goods * in export, bil USD & 29.7 & 33.4 & 31.6 & 28.2 & 26.3 & 16.9 & 15.5 \\
\hline Industrial goods in import, bil USD & 24.3 & 27.2 & 30.6 & 27.4 & 22.2 & 15 & 18.9 \\
\hline $\begin{array}{l}\text { Share of industrial goods in export to } \\
\text { GDP, percent }\end{array}$ & 21.8 & 20.5 & 18.0 & 15.4 & 20.0 & 18.7 & 16.6 \\
\hline $\begin{array}{l}\text { Share of industrial goods in import to } \\
\text { GDP, percent }\end{array}$ & 17.8 & 16.7 & 17.4 & 14.9 & 16.8 & 16.6 & 20.3 \\
\hline GDP of Ukraine, bil USD & 136.4 & 163.1 & 175.7 & 183.3 & 131.8 & 90.6 & 93.2 \\
\hline
\end{tabular}

The share of industrial goods in import to GDP. The indicator is reversed to resilience (Table 8). It demonstrates the dependence of economy on import of goods, which output is not enough in a country, such as machines, equipment, that investment processes and structural shifts in economy are impossible without. For 2010-2016 the share of industrial goods in export to GDP of Ukraine had a tendency to decrease from $21.8 \%$ to $16.6 \%$ that negatively influenced resilience of the industrial sector to shock influences, but this index is within threshold values $-15-40 \%$.

The share of industrial goods in import of Ukraine had a tendency to increase - from $17.8 \%$ in 2010 to $20.3 \%$ in 2016 . The value of this indicator is beyond threshold values $15-20 \%$ that testifies to the threat to resilience in industrial import.

Alongside with it, for determining resilience of the economic production sector to shock influences, namely the level of its dependence on import products that is dependence on changes in economic activity abroad, the share of import in internal consumption (percent) must be analyzed (Table 9). This indicator shows the dependence of national production, including industry, on import of products. The more indicator, the less resilient industrial production of a country is.

Table 9 indicates that the share of import in internal consumption since 2010 grew from $22.2 \%$ to $25.5 \%$ in 2016 . It testifies to the increase of dependence of national economy and industrial production on import of products that negatively influences resilience of the industrial sector. But the value of indicator is within threshold limits $-30 \%$. 
Table 9

Share of import in internal consumption of Ukraine [18, p. 13-14, 20]

\begin{tabular}{|c|c|c|c|c|c|c|c|}
\hline Parameter $\quad$ Year & 2010 & 2011 & 2012 & 2013 & 2014 & 2015 & 2016 \\
\hline Output in market prices, bil hrn & 2507.4 & 3045.2 & 3234.2 & 3260.6 & 3558.2 & 4488.4 & 5420.4 \\
\hline Export of goods and services, bil hrn & 518.4 & 660.9 & 683.5 & 645.6 & 778.7 & 1043.4 & 1173.2 \\
\hline Import of goods and services, bil hrn & 550.0 & 741.0 & 797.1 & 769.1 & 833.5 & 1094.9 & 1337.8 \\
\hline $\begin{array}{l}\text { Share of import in internal consumption, } \\
\text { percent }\end{array}$ & 22.2 & 25.0 & 25.5 & 24.5 & 23.8 & 24.7 & 25.5 \\
\hline
\end{tabular}

Note: Export and import of goods were calculated by the average annual rate of NU by years

So, the results of the analysis of resilience of the industrial sector to external economic activity may be summarized: the Ukrainian industrial sector is within resilience parameters by the indicator of share of industrial goods in export, and not essentially higher threshold values - by the indicator of share of industrial goods in import. It testifies to the stable condition of the industrial sector in the aspect of export activity and not high dependence of resilience of the industrial sector on import. A dependence on import in internal consumption in industry is moderate. A negative factor that influences resilience of industry to shock influences is the low share of products with a high added value, that are high-technological ones, so their export abroad. Export of industrial goods, belonging to the category of high manufacturing degree was $3.1 \%$ in the total export of Ukraine in 2016, at threshold value $10-15 \%$. It testifies to the fact that Ukraine belongs to the group of countries that export raw material. Countries that export mainly raw materials, which share of added price in a final price of a good is low, are dependent from fluctuations of world prices for such products, so have the low resilience level to shock influences.

The share of products, realized at competitive markets to the total volume of products (for the beginning of the year) (Fig. 4). Supports resilience of economy by forming the competitive environment of a country, because the more competitive market is, the faster it can be renewed after shock influences and vice versa.

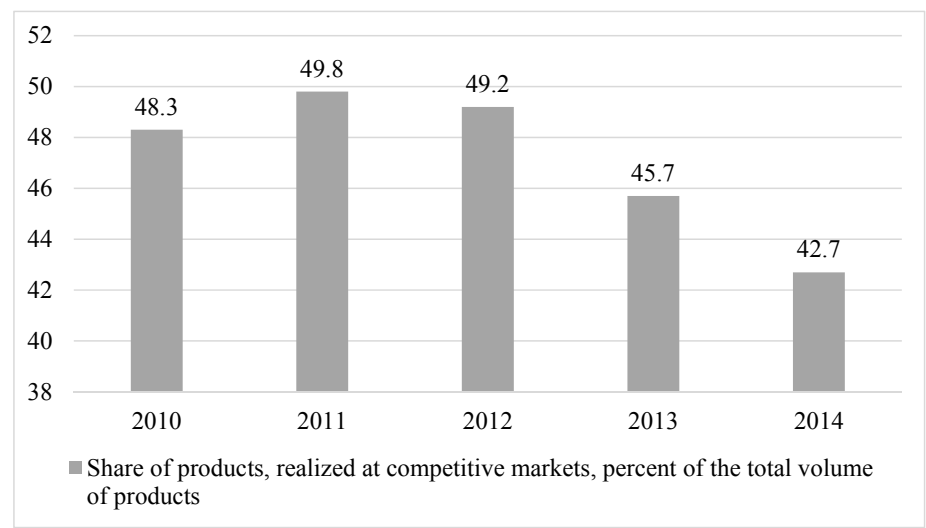

Fig.4. Share of products, realized at competitive markets of Ukraine (for the beginning of the year) [19]

The competitiveness level at Ukrainian markets is low. From 2010 to 2014 the share of products, realized at competitive markets, according to the data of the Antimonopoly committee of Ukraine, was $48.3 \%$ and $42.7 \%$. This index is far beyond the threshold value that is $70 \%$, that testifies to the negative influence on resilience of the economic industrial center.

The important value for resilience of economy in whole and especially industry is inherent to the level of innovative activity of enterprises. This parameter allows to determine long-term prospects of national enterprises and the level of their activity orientation on current factors of competitiveness, which term is rather limited. 
The specific weight of enterprises that introduced innovations in the total number of industrial enterprises (percent). Provides resilience of economy by forming the own environment of production and realization of innovations in industry. It reflects the ability of economy to the intensive growth.

The specific weight of realized innovative products in the volume of industry, percent. Supports resilience of economy by the ability to provide its innovative growth by own forces (national producer).

The low level of innovative activity in whole in industry attracts attention - because the specific weight of enterprises that introduced innovations is $16,6 \%$ of the total number of enterprises [14, p. 504] (Table 10) at threshold indicator value - $30 \%$. If to compare with EU countries, where the level of innovatively oriented enterprises is $50 \%$ and more, the situation in Ukraine looks even more critical.

Table 10

Indicators of innovative activity of industrial enterprises of Ukraine [20]

\begin{tabular}{|c|c|c|c|c|c|c|c|c|c|}
\hline Year & 2000 & 2005 & 2010 & 2011 & 2012 & 2013 & 2014 & 2015 & 2016 \\
\hline $\begin{array}{l}\text { Specific weight of enterprises that introduced in- } \\
\text { novations, percent in the total number of industrial } \\
\text { enterprises }\end{array}$ & 14.8 & 8.2 & 11.5 & 12.8 & 13.6 & 13.6 & 12.1 & 15.2 & 16.6 \\
\hline $\begin{array}{l}\text { Specific weight of realized innovative products in } \\
\text { the total volume, percent }\end{array}$ & 9.4 & 6.5 & 3.8 & 3.8 & 3.3 & 3.3 & 2.5 & 1.4 & - \\
\hline
\end{tabular}

Among leaders by percent of innovatively active enterprises is production of main pharmaceutical products $(47.5 \%)$, computers, electric and optic products $(37.5 \%)$, motor transport vehicles, trailers and semitrailers and other transport $(37.0 \%)$, production of coke and oil manufacturing products $(28.6 \%)$, electric equipment $(28.2 \%)$, chemical substances and products $(27.0 \%)$, machines and equipment (26.2\%) [14, p. 504]. Just these branches belong to high-technological ones, which share, except pharmaceutics, has a tendency to decrease in the total structure of industry.

The specific weight of realized innovative products in the total volume of industrial ones is $1.4 \%$, at threshold value $10-15 \%$. The indicator value shows that Ukraine don't supply own industrial production of innovative products, so depends on external markets that makes economy of the country and correspondingly industry highly dependent on fluctuations of economic activity and external negative influences.

\section{Discussion}

There are many researches, devoted to separating factors that influence resilience of economy in whole and its separate branches. Let's separate factors that favor resilience of the industrial sector to shocks. Foreign scientists [5] determine what sectors of economy are least resilient to shocks, so need more structural reforms. Scientists used for the analysis both general and branch indices of inflation and total output after shock effects in countries. As a result of their study, it was found out that «agriculture and extracting industry" are most resilient sectors, whereas "trade" and "business-services" are least resilient, although there are differences in ranging sectors depending on what shocks are taken into account, ones of demand or supply.

According to the results of the conducted analysis of the indicators of industry resilience to negative external influences (Table 11), we can talk about the non-resilient condition of Ukrainian industry, because eleven of thirteen analyzed indicators are beyond threshold values, and only two indicators: labor intensity of industrial production and share of manufacturing industry in GDP are lower or within the threshold value that is positive for resilience of the industrial sector. 
Table 11

Indicators of resilience of Ukrainian economy to shock influences

\begin{tabular}{lcc}
\hline \multicolumn{1}{c}{ Name of indicator, Units of measurement } & $\begin{array}{c}\text { Threshold } \\
\text { values }\end{array}$ & $\begin{array}{c}\text { Values in } \\
\mathbf{2 0 1 6}\end{array}$ \\
\hline 1. Share of manufacturing industry in GDP, percent & $20-30 \%$ & $28.7 \% *$ \\
2. Employment level of population in industry, percent & $20-30 \%$ & $12.9 \%$ \\
3. Wear and tear degree of main industrial means, percent & $30-60 \%$ & $69.4 \%$ \\
4. Share of high-technological products in the total volume of realized industrial products, percent & $3-5 \%$ & $0.57 \%$ \\
\hline 5. Labor intensity of industrial production, percent & $10-15 \%$ & $8.4 \%$ \\
6. Profitability of operational activity of industrial enterprises, percent & $5-10 \%$ & $4.2 \%$ \\
7. Volume of industrial products with the high manufacturing degree, realized abroad, percent & $10-15 \%$ & $3.1 \%$ \\
8. Share of industrial goods in export to GDP, percent & $15-40 \%$ & $16.6 \%$ \\
9. Share of industrial goods in import to GDP, percent & $15-20 \%$ & $20.3 \%$ \\
10. Share of import in internal consumption, percent & $30 \%$ & $25.5 \%$ \\
11. Share of products, realized at competitive markets, percent of the total volume of products & $70-80 \%$ & $42.7 \% * *$ \\
12. Specific weight of enterprises that introduced innovations in the total number of industrial &
\end{tabular}

Note: *-data for 2015; ** - data for 2014

The aforesaid allows to make a conclusion that in the first 25 years of independence the pseudo-resilient socio-economic system formed in Ukraine. The role of industry in it decreases more and more. On the background of the general decrease of the role of industry in Ukrainian economy, regress is observed in technological orders - from high to low ones: the share of manufacturing industry decreases, especially one of such high-technological part as machine engineering, and the share of raw material branches increases synchronously.

\section{Conclusions}

The results of the conducted analysis of resilience of Ukrainian industry to shock influences allow to state:

1. Resilience of economy to shocks is the ability of the economic industrial sector to react and adjust to both internal and external irritants, keeping stable rates of the economic growth. This is just the "protective barrier" in the industrial sector that allows it to function stably, timely adjusting to changes in the external environment.

2. The share of manufacturing industry in GDP of Ukraine for 2001-2015 had a tendency to decrease and was $28.7 \%$, but within the threshold values as $20-30 \%$ of GDP. There is traced the structural unevenness of industrial production with predominance of extracting industry over manufacturing one. It testifies to the resource directionality of Ukrainian economy and products with a low share of added value. Industrial production in Ukraine transforms in one of the low-technological order, the raw material specialization gains momentum at the synchronous reduction and almost complete liquidation of high-technological production branches that is reflected on the condition of internal market, low share of own production goods.

The number of employed in industry has a stable tendency to decrease, which rates are higher than average in economy of Ukraine. If in 2000 it reached $22.8 \%$ of the whole employed population, in $2016-12.9 \%$. The index of employment level of the population in industry of the country is beyond the threshold value as $20 \%$ that negatively influences resilience of the economic industrial center. 
The condition of main means in industry prevents resilience of the Ukrainian economic industrial center. The wear and tear degree of main means for 2016 in economy of the country was $58.1 \%$, in industry $-69.4 \%$ that testifies to the critical level of wear and tear of main means of Ukraine, because the threshold value of this parameter is $35 \%$

The indicator of the share of high-technological products in the total volume of realized industrial products in Ukraine for 2017 was only $0.5 \%$. This indicator has a stable tendency to decline since 2001, when it was $2.94 \%$. So, resilience of the industrial sector is threatened, because the threshold value of the parameters is $3-5 \%$.

The labor intensity of industrial production in Ukraine has a tendency to decline that positively influences the resilience level of the economic industrial sector, being $8.4 \%$ in 2016 and remaining lower the threshold values that are $10-15 \%$.

At that the profitability level of industrial enterprises remains low and is $4.2 \%$, at threshold values 5-10\%. It testifies to the low resilience of industrial enterprises, because they are not able to guarantee a "financial pillow" of resilience for themselves in a case of shock fluctuations in economy.

In 2010-2016 the share of industrial goods in export to GDP of Ukraine had a tendency to decrease from $21.8 \%$ to $16.6 \%$ that negatively influenced resilience of the industrial sector to shock influences, but the value of this parameters is within threshold values $-15-40 \%$.

The share of industrial goods in import of Ukraine had a tendency to increase - from $17.8 \%$ in 2010 to $20.3 \%$ in 2016 . The value of this indicator is beyond the threshold values as $15-20 \%$ that indicates the threat to resilience in industrial import.

A negative factor that influences resilience of Ukrainian industry is the low share of products with a high added value, that are high-technological ones, so their export abroad. Export of industrial goods, belonging to the category of high manufacturing degree was $3.1 \%$ in the total export of Ukraine in 2016, at threshold value 10-15\%. So, Ukraine belongs to the group countries that export mainly raw materials, which share of added price in a final price of a good is low, are dependent from fluctuations of world prices for such products, so have the low resilience level to shock influences.

The competition level at Ukrainian markets is low. From 2010 to 2014 the share of products, realized at competitive markets, according to the data of the Antimonopoly committee of Ukraine, was $48.3 \%$ and $42.7 \%$. This index is far beyond the threshold value that is $70 \%$, that testifies to the negative influence on resilience of the economic industrial center.

The low level of innovative activity in whole in industry attracts attention $-16.6 \%$ of the total number of enterprises (the threshold indicator value is $30 \%$ ). If to compare with EU countries, where the level of innovatively oriented enterprises is $50 \%$ and more, the situation in Ukraine looks even more critical.

The specific weight of realized innovative products in the total volume of industrial ones is $1.4 \%$, at threshold value $10-15 \%$. The indicator value shows that Ukraine doesn't supply own industrial production of innovative products, so depends on external markets. It forms the high dependence of economy of the country and especially industrial sector on fluctuations of economic activity.

So, according to the results of the conducted analysis of the indicators of industry resilience to negative external influences, we can talk about the non-resilient condition of Ukrainian industry, because eleven of thirteen analyzed indicators are beyond threshold values, and only two indicators: labor intensity of industrial production and share of manufacturing industry in GDP are lower or within the threshold value that is positive for resilience of the industrial sector.

3 . The results of the statistical analysis of reactions of Ukrainian industry to shock influences, namely world crisis of 2008-2009 and national crisis of 2013-2014 indicate the coincidence between economic braches of Ukraine and EU by the resilience level. The least resilient economic industrial branches of Ukraine are: machine engineering, including motor transport vehicles and other transport; metallurgical production, metal processing; chemical substances and products. The most resilient branches of Ukrainian industry are: food industry, production of pharmaceutical products and preparations. 
4. Guaranteeing of resilience of the economic industrial sector to negative external influences needs changing a paradigm of the economic policy of the state: refusal of liberal conceptions, where the state had a role of a side observer of economic processes and transfer to active forms of the state influence of economy.

For providing the growth of industrial production in separate regions of Ukraine, it is necessary to create base productions that are the ground of one or another product and determine its technical and consumption parameters. In industry there are: production of engines of different types and destinations, semiconductors and microelectronics, constructor materials, diverse products of inter-branch destination.

\section{Limitations}

The data of different periods of 2015-2016 by several indicators and parameters are used in the paper, because at the moment of writing it, official sources didn't contain more urgent information.

\section{Acknowledgements}

This article was prepared and funded within the research theme "The conceptual and paradigm shifts in economics of XXI century" reg. No. 0118U000126 of Economic Theory and Competitive Policy department of Kyiv National University of Trade and Economics.

\section{References}

[1] Ahn, S. (2002). Competition, Innovation and Productivity Growth: A Review of Theory and Evidence. SSRN Electronic Journal. doi: https://doi.org/10.2139/ssrn.318059

[2] Blanchard, O., Wolfers, J. (2000). The Role of Shocks and Institutions in the Rise of European Unemployment: the Aggregate Evidence. The Economic Journal, 110 (462), C1-C33. doi: https://doi.org/ 10.1111/1468-0297.00518

[3] Structural Policies and Economic Resilience to Shocks. (2007). OECD Economics Department Working Papers. doi: https://doi.org/10.1787/140152385131

[4] Eurostat. Available at: http://ec.europa.eu/eurostat/web/structural-business-statistics/data/main-tables

[5] Gerasymenko, A., Borovyk, I., Afendikova, S. (2017). The methodology of competition assessment. Economic Annals-XXI, 165 (5-6), 52-55. doi: https://doi.org/10.21003/ea.v165-11

[6] Grenouilleau, D., Ratto, M., Roeger, W. (2007). Adjustment to shocks: a comparison between the Euro Area and the US using estimated DSGE models. Paper prepared for the OECD Workshop «Structural reforms and economic resilience: evidence and policy implications». Paris, 38.

[7] Kuznetsova, A., Azarenkova, G., Olefir, I. (2017). Implementation of the "bail-in" mechanism in the banking system of Ukraine. Banks and Bank Systems, 12 (3), 269-282. doi: https://doi.org/10.21511/ bbs.12(3-1).2017.11

[8] Measuring the macroeconomic resilience of industrial sectors in the EU and assessing the role of product market regulations. (2012). European Commission. European Economy. Occasional Papers, No. $112,84$.

[9] Pelkmans, J., Acedo, L., Maravalle, A. (2008). How product market reforms lubricate shock adjustment in the euro area. European Economy. Economic Papers, No. 341, 43. doi: http://oi.org/ $10.2765 / 95969$

[10] Ponomarenko, T., Khudolei, V., Prokopenko, O., Klisinski, J. (2018). Competitiveness of the information economy industry in Ukraine. Problems and Perspectives in Management, 16 (1), 85-95. doi: https://doi.org/10.21511/ppm.16(1).2018.08

[11] Tengeh, R. K. (2017). Entrepreneurial resilience: the case of Somali grocery shop owners in a South African township. Problems and Perspectives in Management, 14 (4), 203-211. doi: https://doi.org/ 10.21511/ppm.14(4-1).2016.09

[12] Site of the State Statistics Service of Ukraine. Available at: http://www.ukrstat.gov.ua 
[13] Sonko, Y., Lazebna, I., Lebedeva, L. (2018). Material production and GDP in Ukraine: theoretical concept and financial assessment. Investment Management and Financial Innovations, 15 (2), 51-59. doi: https://doi.org/10.21511/imfi.15(2).2018.05

[14] The EU Economy 2006 Review - Adjustment Dynamics in the Euro Area: Experiences and Challenges (2006). European Commission. European Economy, No. 6, 372.

[15] Zvit Antymonopolnoho komitetu Ukrainy za 2014 rik (2015). Antimonopoly committee of Ukraine, 140. Available at: http://www.amc.gov.ua/amku/doccatalog/document?id=110270\&schema=main

[16] Zovnishnia torhivlia Ukrainy tovaramy ta posluhamy u 2013 rotsi (2014). Kyiv, 157.

[17] Zovnishnia torhivlia Ukrainy tovaramy ta posluhamy u 2016 rotsi (2017). Kyiv, 153.

[18] Metodychni rekomendatsiyi shchodo rozrakhunku rivnia ekonomichnoi bezpeky Ukrainy (2013). Ministry of Economic Development and Trade of Ukraine, No. 1277.

[19] Natsionalni rakhunky Ukrainy za 2016 rik (2018). Kyiv, 13-14.

[20] Platizhnyi balans Ukrainy na 2017 r. (2017). National Bank of Ukraine publising. Available at: https://bank.gov.ua/control/uk/publish/article?showHidden=1\&art_id=65613\&cat_id=44446

[21] Statystychnyi shchorichnyk Ukrainy za 2016 rik (2017). Kyiv, 608. 